HARRAN ÜNIVERSITESI MÜHENDISLIK FAKÜLTES:

HARRAN ÜNIVERSITESI MÜHENDISLIK DERGisi

HARRAN UNIVERSITY JOURNAL OF ENGINEERING

e-ISSN: 2528-8733

\section{HARRAN ÜNIVERSITESİ MÜHENDİSLİK DERGISİ}

HARRAN UNIVERSITY JOURNAL of ENGINEERING

e-ISSN: 2528-8733 (ONLINE)

URL: http://dergipark.gov.tr/humder

Parafine Eklenen Farklı Nanopartiküllerin Isıl Performans Üzerine Etkisinin Deneysel Olarak İncelenmesi

Experimental Investigation of The Effect of Different Nanoparticles Addition on The Thermal Performance of Paraffin

Yazar(lar) (Author(s)): Nergiz ÜLKER', Hüsamettin BULUT2 2, Yunus DEMIRTAŞ3, Gökhan DEMIRCAN ${ }^{4}$

1 ORCID ID: 0000-0002-6079-4792

2 ORCID ID: 0000-0001-7123-1648

3 ORCID ID: 0000-0003-2200-0370

4 ORCID ID: 0000-0002-9579-6878

Bu makaleye şu şekilde atıfta bulunabilirsiniz (To cite to this article): Ülker N., Bulut $H_{\text {., }}$ Demirtaş Y., Demircan G., "Parafine Eklenen Farklı Nanopartiküllerin Isıl Performans Üzerine Etkisinin Deneysel Olarak İncelenmesi”, Harran Üniversitesi Mühendislik Dergisi, 5(2): 134-145, (2020).

Erişim linki (To link to this article): http://dergipark.gov.tr/humder/archive 


Mühendislik Dergisi

\title{
Parafine Eklenen Farklı Nanopartiküllerin Isıl Performans Üzerine Etkisinin Deneysel Olarak İncelenmesi
}

\author{
Nergiz ÜLKER ${ }^{1}$, Hüsamettin BULUT ${ }^{1, *}$, Yunus DEMIRTAŞ ${ }^{1}$, Gökhan DEMIRCAN ${ }^{1}$ \\ ${ }^{I}$ Harran Üniversitesi, Mühendislik Fakültesi, Makine Mühendisliği Bölümü, Şanlurrfa
}

Öz

Makale Bilgisi

Başvuru: $18 / 05 / 2020$

Düzeltme: $15 / 06 / 2020$

Kabul: 11/07/2020

\section{Anahtar Kelimeler}

Gizli Enerji Depolama

Parafin

Nanopartikül

$\mathrm{MgO}$

$\mathrm{ZnO}$

$\mathrm{SiO}_{2}$

\section{Keywords}

Latent Heat Storage

Paraffin

Nanoparticle

$\mathrm{MgO}$

$\mathrm{Zn}$

$\mathrm{SiO}_{2}$
Is1 depolama, enerjinin tasarruflu ve verimli kullanılabilmesi için günümüzde araştırmaların üzerine yoğunlaştığ 1 bir konudur. Isı depolamanın bir çeşidi olarak gizli 1sıyı depolamada faz değişim maddeleri (FDM) kullanılmaktadır. Ancak, enerji depolamada yaygın olarak kullanılan maddelerden parafinin düşük 1sıl iletkenliğe sahip olması önemli bir problem olarak ortaya çıkmaktadır. Bu problemi çözme yöntemlerinden biri parafinde nanopartiküllerin kullanılmasıdır. Yapılan deneysel çalışmada parafine $\% 1, \% 2.5$ ve $\% 5$ oranlarında $\mathrm{MgO}, \mathrm{ZnO}$ ve $\mathrm{SiO}_{2}$ nanopartikülleri ekleyerek parafinin şarj ve deşarj işlemleri incelenmiştir. Sonuç olarak, \%1 nanopartikül katkısının parafinin ısıl performasına etki etmediği ve $\mathrm{ZnO}$ nanopartikülün parafinde şarj ve deşarj işlemlerinde daha iyi performans gösterdiği ve $\% 2.5$ kütle oranın daha iyi olduğu tespit edilmiştir. Ayrıca nanopartikül katkısının parafinde şarj işleminde erime ve sonrasında veya deşarj işleminde donma ve sonrasında farklı etki ettiği gözlemlenmiştir.

\section{Experimental Investigation of The Effect of Different Nanoparticles Addition on The Thermal Performance of Paraffin}

\begin{abstract}
Heat storage is an issue that research focuses on in order to use energy economically and efficiently. As one of heat storage types, phase change material (PCM) are used in latent heat storage. However, the low thermal conductivity of paraffin, which is one of the materials commonly used in energy storage, appears to be an important problem. One of the methods of solving this problem is the use of nanoparticles in paraffin. In this experimental study, the charge and discharge processes of paraffin were investigated by adding $1 \%, 2.5 \%$ and $5 \% \mathrm{MgO}, \mathrm{ZnO}$ and $\mathrm{SiO}_{2}$ nanoparticles to paraffin. As a result, it has been determined that $1 \%$ nanoparticle additive does not affect the thermal performance of paraffin, and $\mathrm{ZnO}$ nanoparticle performs better in charge and discharge processes and the mass ratio is $2.5 \%$ better. In addition, it was observed that the nanoparticle additive had a different effect on during melting after in the charging process, and during freezing and after in the discharge process.
\end{abstract}

\section{GİRIŞ (INTRODUCTION)}

Dünya genelinde artan nüfus ve ekonomiye bağlı olarak ihtiyaç duyulan enerji talebinin de artmasıyla birlikte fosil yakıtların hızla yakılması sonucunda hem enerji kaynakları hızla tükenmekte hem de yüksek oranlardaki $\mathrm{CO}_{2}$ ve diğer sera gazlarının salınımı sonucunda küresel ısınma problemi artmaktadır. Fosil yakıtların yenilenemez oluşu ve çevreye olan zararlarından dolayı rüzgâr, güneş enerjisi gibi daha temiz olan yenilenebilir enerji kaynaklarını kullanmak umut vaat eden bir çözüm yolu olmuştur. Bu doğrultuda enerji kaynaklarında tasarrufu, sistem verimliliğinde ise artışı sağlayan enerji depolama gündeme gelmiştir. Böylece enerji depolama ile, tükenme tehlikesi olan fosil kaynakların korunması, $\mathrm{CO}_{2}$ ve diğer sera gazlarının salınımının azaltılması ve yenilenebilir, temiz ancak sürekli olmayan güneş, rüzgâr gibi enerji kaynaklarının da sürdürülebilir hale gelmesi sağlanmaktadır [1-5]. 
Mevcut olan enerji kaynakları arasında termal enerji, doğada bulunabilirlik açısından en fazla kaynağa sahip enerji türü olduğundan dolayı tasarruflu ve verimli enerjinin sağlanmasında termal enerji depolama uygulamaları daha fazladır. Termal enerji depolama yöntemleri yenilenebilir enerji kaynaklarının var olduğu zamanlarda depo edilerek kaynakların kesintiye uğradığı zamanlarda kullanılmasını sağlayarak enerjinin üretilmesi ve tüketilmesi arasındaki süre uyuşmazlığını ortadan kaldırmaktadır [4-9].

Termal enerji depolama yöntemleri, birim hacimde depolayabildikleri enerji bakımından duyulur 1s1 depolama, gizli 1s1 depolama ve termokimyasal 1s1 depolama olarak ayrılmaktadır [10]. Duyulur 1s1 depolamada materyalin sıcaklığında meydana gelen değişim sonucu oluşan 1sıdan faydalanılır. Duyulur 1sı ile depolanan enerji;

$\mathrm{Q}=\mathrm{m} \cdot \mathrm{C}_{\mathrm{p}} \cdot \Delta \mathrm{T}$

denklemi ile hesaplanabilir. Burada, $\mathrm{Q}$, depo edilen 1sı miktarı, $\mathrm{m}$, depolama malzeme kütlesi $(\mathrm{kg}), \mathrm{C}_{\mathrm{p}}$, depolama malzemesinin özgül $1 \mathrm{~s} 1 \mathrm{~s} 1(\mathrm{~kJ} / \mathrm{kgK})$ ve $\Delta \mathrm{T}$ ise şarj işleminde meydana gelen sıcaklık (K) değişimidir. Buradan depo edilebilecek olan 1sı miktarının sıcaklıktaki değişim oranına, ortamın sahip olduğu 1sı kapasitesine ve depolamada kullanılacak olan materyalin miktarına bağlı olduğu sonucuna varılmaktadır [1]. Duyulur 1sı depolamada ihtiyaç duyulan 1sı deposu hacminin büyük olması bu yöntemin dezavantajidır [10].

Gerçekleşen kimyasal bir tepkime sırasında alınan ya da verilen ısının ihtiyaç duyulan zamanda kullanılmak üzere depo edildiği yönteme termokimyasal 1sı depolama yöntemi denir. Termokimyasal 1sı depolama yönteminin ana prensibi, ekzotermik olarak tepkimeye giren iki ya da daha fazla kimyasal bileşikte gerçekleşen kimyasal tersinir tepkimeler boyunca kimyasal bağlarda 1sının depo edilmesidir [10].

Isı depolamada kullanılacak olan materyallerin faz değişimi esnasında materyallerin aldığı veya verdiği 1sıya gizli 1sı denir. Bu faz değişimi sırasında erime-kaynama gibi düzensizliğin arttı̆̆ durumlarda sistemden enerji alınırken donma-yoğunlaşma gibi düzensizliğin azaldığı durumlarda 1Sı verilir. Gerçekleşen bu faz değişimleri sırasında 1sı, gizli 1sı olarak depolanmaktadır. Depo edilen gizli 1sı miktarı;

$\mathrm{Q}=\mathrm{m} \cdot \Delta \mathrm{h}$

denklemi ile hesaplanır. Burada Q, depolanan gizli 1sı miktarı (kJ), m, depolama malzemesinin kütlesi (kg) ve $\Delta \mathrm{h}$ ise faz değişim entalpisidir (kJ/kg) [5]. Gizli 1sıyı depolayan maddelere faz değiştiren maddeler (FDM) denir. Organik FDM grubuna giren parafinler, geniş bir sıcaklık aralığına sahip olup yüksek gizli 1S1 değerlerine sahip olmaları, ucuz olup bol miktarda bulunmaları, kimyasal açıdan kararlı davranmaları, uzun ömürlü olup sabit sıcaklıkta yüksek enerji depo edebilme yoğunluğuna sahip olmaları sebebiyle 1sı depolamada yaygın bir şekilde kullanılırlar. Ancak parafinlerin termal enerji depolama sistemlerinde FDM olarak kullanılmasındaki en büyük sorun düşük ısıl iletkenliğe sahip olmalarıdır. Bu problemin önüne geçmek adına bazı metotlar geliştirilmiştir. Bunlardan nanopartiküllerin FDM'ye ilave edilmesi yaygın olan yöntemlerdendir. Burada nanopartiküllerin yüksek 1sıl iletkenliğe sahip olmalarıyla ilave edilen FDM'nin ısıl iletkenliklerinde artışa yol açarken, düşük yoğunluğa sahip olmalarının yanında boyutlarının küçük olmasına bağlı olarak artan yüzey/hacim oranıyla birlikte ise 1sı transfer hızını arttırmaktadırlar [1,11-15].

Gizli 1sı depolama yönteminin diğer depolama yöntemlerine göre avantajları şöyledir:

> Gizli 1S1 depolama, duyulur 1s1 depolamaya nazaran termal enerji depolama kapasitesi daha yüksektir ve en önemlisi gerekli olan depo hacmi daha küçüktür.

$>$ FDM olarak kullanılan materyallerin termal enerji depolama kapasiteleri birim kütle için daha yüksektir. Faz dönüşüm sıcaklıkları sabit sıcaklıkta depo etme ve geri kazanım için elverişlidir.

$>\mathrm{Bu}$ yöntemin kullanımı sabit sıcaklıkta ısı gereksinimi duyan maddeler için elverişlidir [10].

Gizli ısı depolama yönteminin dezavantajları şöyle sıralanabilir:

$>$ Isı depolama esnasında yoğunluk değişimi oluşabilir.

> FDM'ler düşük 1sıl iletkenliğe sahiptirler. 
$>$ Uzun vadeli kullanımın söz konusu olduğu durumlarda materyallerin yapısında kararsızlıklar meydana gelir.

$>$ FDM'lerde faz ayrışması veya aşırı soğuma olabilir [10].

Gizli ısı depolamanın uygulandığı durumlar şunlardır:

$>$ Kisa vadeli depolamada

$>$ Yüksek enerji kapasitesi ya da yüksek enerji yoğunluğu ihtiyacı olduğunda

$>$ Depo hacminin küçük olması gerektiği yerlerde

> Sabit veya küçük bir sıcaklık aralığında enerji depolamaya gereksinim duyulduğunda [12].

Gizli enerji depolamada en çok kullanılan madde parafindir. Ancak parafinin 1S1 iletiminin düşük olması önemli bir problemdir. Parafinin 1sı iletimini artırmak için parafine değişik nanoparçacıklar katılarak değerli araştırmalar yapılmıştır. Aşağıda bazı değerli çalışmalar özetlenmiştir.

Taşkıran [10] yaptığı çalışmada, 17 adet farklı türde FDM seçmiş ve bunlara eklenmesi için bakır oksit $(\mathrm{CuO})$, alüminyum oksit $\left(\mathrm{Al}_{2} \mathrm{O}_{3}\right)$ ve grafit nanofiber (GNF) olmak üzere 3 tane nanopartikül kullanmıştır. Seçilen FDM'nin içerisine ağırlıkça $\% 1, \% 1.5, \% 2, \% 5$ ve $\% 10$ oranlarında nanopartiküller ilave edilerek, bu karışımların termal özellikleri incelenmiştir. Yapılan deneyler sonucunda, FDM'ye nanopartikül ilavesinin FDM'nin hem termal özelliklerini hem de erime/katılaşma sürelerini iyileştirdiği tespit edilmiştir. Elbahjoui ve Qarni [16] yaptıkları çalışmada düz plakalı güneş kolektörüyle birleştirilmiş olan dikdörtgen plakalardan oluşan 1s1 depolama ünitesini kullanarak RT50 FDM'ye $\mathrm{Al}_{2} \mathrm{O}_{3}$ nanopartiküllerinin ilave edilmesinin termal etkiye davranışı ve depolamaya etkisini incelemişlerdir. Su kolektörde dolaşarak güneş enerjisini alarak emici alan oluşturmuş ve nanopartikül katkılı FDM içeren levhalar arasında 1sıyı iletmek için dolaşmıştır. Sonuçta nanopartikül katkılı FDM lerin depolama verimliliğini arttırdığı sonucuna varılmıştır. $W u$ ve ark. [17] parafinin ısıl performansını arttırmak amacıyla parafin içerisine ağırlıkça \%0.5 ve $\% 1$ oranlarında Bakır $(\mathrm{Cu})$, Alüminyum $(\mathrm{Al})$ ve Karbon/Bakır $(\mathrm{C} / \mathrm{Cu})$ nanoparçacıklarını ilave ederek yeni bir nanoakışkan FDM hazırlamışlardır. Hazırlanmış olan nanokompozitlerden $\mathrm{Cu}$ nanopartikül ilaveli FDM'nin en iyi 1sıl performansı gösterdiği gözlemlenmiş ve bu kompozit ile saf parafinin şarj/deşarj döngüsü incelenmiştir. \%1 Cu-parafin nanokompozitinin erime ve katılaşma süresinin sirasıyla $\% 30.3$ ve $\% 28.2$ azaldığ 1 tespit edilmiştir. Ho ve Gao [18] FDM olarak n-oktadekan(parafin) ve kütlece \%0, \%5 ve \%10 nanopartikül $\left(\mathrm{Al}_{2} \mathrm{O}_{3}\right)$ kullandıkları çalışmalarında deneyleri $25 \times 25 \mathrm{~mm}$ boyutlarında $60 \mathrm{~mm}$ uzunluğunda yalıtımlı bir depo kullanarak gerçekleştirmişlerdir. Yoğunluk, dinamik viskozite ve termal iletkenlik gibi termofiziksel özellikleri deneysel olarak inceledikleri benzer bir çalışmada nanoparçacık eklenen parafin emülsiyonları için ölçülen 1sıl iletkenlik ve dinamik viskozite değerlerinin, sıcaklığa bağlı olarak, saf parafin ile karşılaştırıldığında nanopartiküllerin kütle fraksiyonu ile doğrusal olmayan bir artış gösterdiği belirlenmiştir. Jesumathy ve ark. [19] deneysel olarak yapmış oldukları çalışmalarında, FDM olarak parafini kullanmış ve içerisine termal iletkenliği artırmak için farklı kütlesel oranlara sahip bakır oksit nanoparçacıklar kullanılarak dikey bir silindir içerisinde saf parafin ile bakır oksit eklenmiş olan parafinin termal iletkenlikleri ve termal karakteristikleri üzerine etkisini incelemişlerdir. Yapılan deneysel sonuçlar, bakır oksit eklenmiş olan parafinin saf parafine oranla erime/katılaşma sürelerinde azalmalar ve termal iletkenliklerde yükselmeler olduğu tespit etmişlerdir. Fan ve ark. [20] parafin içerisine ağırlıkça \%15 arasındaki oranlarda değişen karbon nanotüpleri, karbon nano elyafları ve grafen nanoplateletleri (GNP) ilave edip nanokompozit numuneler hazırlamışlardır. Nanokompozit FDM'lerin 1sıl iletkenliklerinin yükleme oranının arttırılmasıyla arttığı görülmüş ve bu artış miktarının nanodolgu maddelerinin boyut ve şekline bağlı olduğu belirlenmiştir.

Wang ve ark. [21] parafin içerisine ağırlıç̧a \%1, \%2 ve $\% 5$ oranlarında $\mathrm{Al}_{2} \mathrm{O}_{3}$ nanopartiküllerini ilave ederek nanokompozitler hazırlamı̧ ve bu numunelerin termal analizleri yapılııştır. Sonuç olarak ise ilave edilen nanoparçacık miktarının arttırılmasıyla parafinin erime noktalarında düşüş, gizli isı ve 1sıl iletkenlik değerlerinde ise artış gözlemlenmiştir. Parlak ve ark. [22] FDM olarak seçilen parafine ağırlıkça \%1, \%3, $\% 5, \% 7$ ve $\% 10$ oranlarında grafen nanoplateletin ilave edilmesiyle elde edilen kompozitin 1sil performansını ve enerji depolama özelliklerini incelemişlerdir. Yapılan analizler sonucunda ise parafine grafen nanoplateletin ilavesinin 1sıl iletkenlik değerlerinde artışa yol açtığ [23] parafin içerisine ağırlıķa \%5, \%10 ve \%15 oranlarında $\mathrm{Fe}_{3} \mathrm{O}_{4}, \mathrm{CuO}, \mathrm{TiO}_{2}$ ve $\mathrm{ZnO}$ nanopartiküller ilave edilmesiyle hazırlanan nanokompozitlerin termal özelliklerini incelemişlerdir. Sonuç olarak ise 
parafine nanopartikül ilavesinin gizli 1sı değerinde artışlara sebep olduğu belirlenmiştir. $\% 5$ oranında $\mathrm{CuO}$ nanopartikül içeren nanokompozitte en büyük artış gözlemlenirken en düşük artışın ise $\% 15$ oranında $\mathrm{TiO}_{2}$ nanopartikül içeren nanokompozitte olduğu görülmüştür. Tan ve ark. [24] FDM olarak RT27 maddesine $\mathrm{Cu}$ nanopartiküllerini ilave ederek elde ettikleri nanokompozitlerin küresel bir kap içerisindeki erime davranışını sayısal olarak incelemiştir. Sonuç olarak ise 1sıl iletkenlikte artış görülmüştür. Bu sayede erime hızının arttığı ve böylece erime sürelerinde azalmaların olduğu tespit edilmiştir. Nourani ve ark. [25] FDM'lerden parafine ağırlıkça $\% 2.5, \% 5, \% 7.5$ ve $\% 10$ oranlarında $\mathrm{Al}_{2} \mathrm{O}_{3}$ nanopartiküllerini ilave ederek hazırlanan numunelerin ssıl performansını incelemişlerdir. Yapılan deneyler sonucunda hazırlanan kompozitlerin 1sıl iletkenliklerinde artış sağlanmış ve dolayısıyla da erime/donma sürelerinin azaldığı gözlemlenmiştir. Mandal ve ark. [26] parafinin içerisine ağırlıkça $\% 0.25, \% 0.5, \% 0.75$ ve $\% 1$ oranlarında $\mathrm{CuO}$ nanopartiküllerini ilave ederek nanokompozitler hazırlanmış ve termal analizleri yapılmıştır. Sonuç olarak ise $\mathrm{CuO}$ nanopartiküllerinin ilave edilmesiyle parafinin 1sıl iletkenliğinin ve dolayısıyla 1sı transfer hızının arttığı tespit edilmiştir. Kim ve Drzal [27] sıvı parafin içerisine ağırlıkça \%1, \%2, \%3, \%5 ve \%7 oranında grafit nanoplateleti (xGNP) ilave ederek nanokompozitler hazırlamış ve bu numunelerin isıl performansını incelemişlerdir. Sonuç olarak ise ilave edilen xGNP oranındaki artışa bağlı olarak hem 1sıl hem de elektriksel iletkenlikte artışların olduğu tespit edilmiştir. Ebrahimi ve Dadvand [28] parafine ağırlıkça $\% 2$ ve $\% 5$ oranlarında $\mathrm{Al}_{2} \mathrm{O}_{3}$ nanopartiküllerinin ilave edilmesiyle nanokompozitler hazırlamış ve bunların termal analizlerini yapmışlardır. Sonuç olarak ise nanopartikül ilavesiyle parafinin 1sıl iletkenliğinde artışlar gözlemlenmiş ve ağırlıkça \%2 oranında nanopartikül içeren kompozitin en yüksek erime hızını gösterdiği belirlenirken ağırlıkça $\% 5$ oranında nanopartikül içeren kompozitin erime hızının saf parafininkine yakın olduğu tespit edilmiştir. $L i$ [29] parafine ağırlıça $\% 0, \% 1, \% 4, \% 7$ ve \%10 oranlarında nano grafit (NG) ilave ederek nanokompozitler hazırlamışıır. İlave edilen NG miktarının artmasına bağlı olarak ısıl iletkenlik değerlerinin arttığı ve parafinin verimlilik açısından enerji depolama performansının iyileştiği gözlemlenmiştir.

Literatür araştırmasından parafine $\% 1$ ile $\% 10$ arasında değişik oranlarda nanopartikül katıldığ 1 ve nanopartikülün genelde 1sıl iletkenliğini artırdığı tespit edilmiştir. Bu çalışmada, \%1, \%2.5 ve \%5 oranlarında $\mathrm{MgO}, \mathrm{SiO}_{2}$ ve $\mathrm{ZnO}$ nanopartikül katkılı parafinde 1s1 enerjisinin, gizli 1s1 olarak depolanmas1 araştırılmıştır.

\section{MATERYAL VE METOT (MATERIAL and METHOD)}

FDM olarak seçilmiş olan parafinin ısıl özelliklerini iyileştirmek amacıyla ağırlıç̧a \%1, \%2.5 ve \%5 oranlarında $\mathrm{MgO}, \mathrm{SiO} 2$ ve $\mathrm{ZnO}$ nanopartikülleri parafine ilave edilerek nanokatkılı parafin numuneleri hazırlanmıştır. Önce seçilmiş olan nanopartiküller hassas terazi yardımıyla numune kabı içerisine $\% 1, \% 2,5$ ve $\% 5$ oranlarında konulmuştur. Daha sonra numune kabındaki nanopartiküllerin ilave edilecek olan parafin içerisinde homojen dağılımını sağlamak amacıyla, ses dalgaları oluşturarak nanopartiküller arasındaki fiziksel bağı kırıp partiküllerin sıvı içerisinde homojen dağılmalarını sağlayan ultrasonik karıştırıcı kullanılmıştır. Kullanılan ultrasonik karıştırıcı Şekil 1'de gösterilmiştir. Karıştırıcı herhangi bir sıcaklık ayarı yapılmadan \%70 genlik değerine ayarlanmış ve numuneler 1 saat boyunca karıştırılmıştır. Karıştırıcıdan $100^{\circ} \mathrm{C}$ ve üzeri bir sıcaklıkta alınan numuneler öncelikle teker teker deney setine konularak 1 saat boyunca ortam havası ile deşarj işlemine tabi tutulmuşlardır. Daha sonra ise nanoparçacık katkılı parafinler oda sıcaklığında soğumaya bırakılmış ve üçlü gruplar halinde 1 saat boyunca şarj/deşarj işlemleri incelenmiştir. Şarj işleminde fanlı 1sıtıcıdan çıkan hava hızı $3.5 \mathrm{~m} / \mathrm{s}$; deşarj işleminde ise $3 \mathrm{~m} / \mathrm{s}$ olarak ölçülmüştür. Şarj/deşarj işlemleri gerçekleştirildiği deney seti Şekil 2 ve Şekil 3'te gösterilmiştir. Test odasında numuneler üzerinde homojen bir hava dağılımı olması için hava borusu uzun yapılmıştır. Sıcaklık ölçümleri için T tipi isıl çiftler kullanılmış ve ölçümler datalogger'da kaydedilmiştir. Test bölgesine hava giriş ve test bölgesinden hava çıkış sıcaklıkları, dış ortam sıcaklığı ve her bir numunenin ortasından nano katkılı parafinin sıcaklığı ölçülmüştür. Hazırlanan nanoparçacık katkı1ı parafinler Şekil 4, Şekil 5 ve Şekil 6'da gösterilmiştir. Şekillerden numunelerde herhangi bir renk farkının olmadığı görülmektedir. 


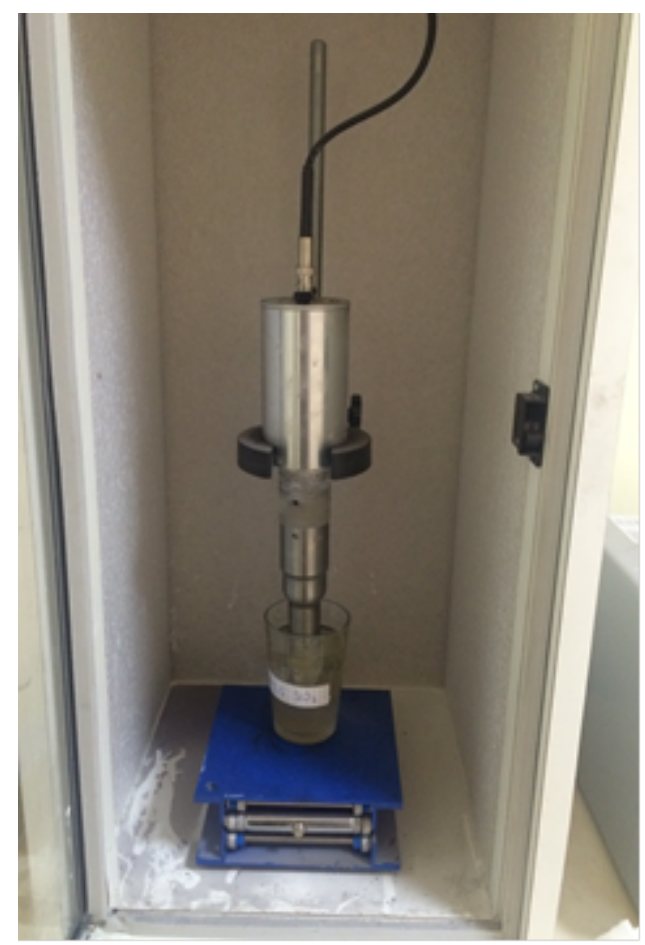

Şekil 1. Ultrasonik karıştırıcı

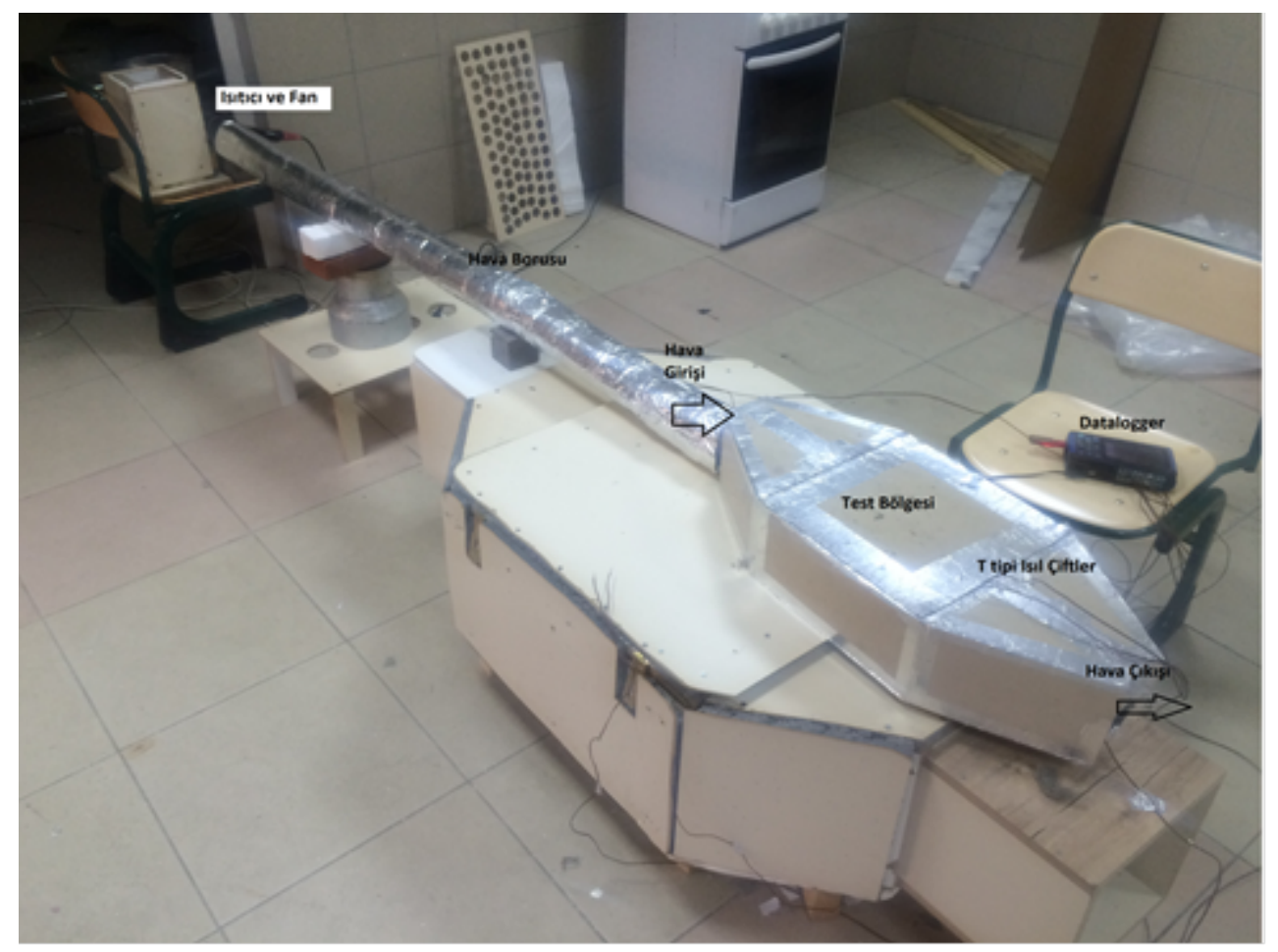

Şekil 2. Şarj ve desarj döngülerinde kullanılan deney seti 


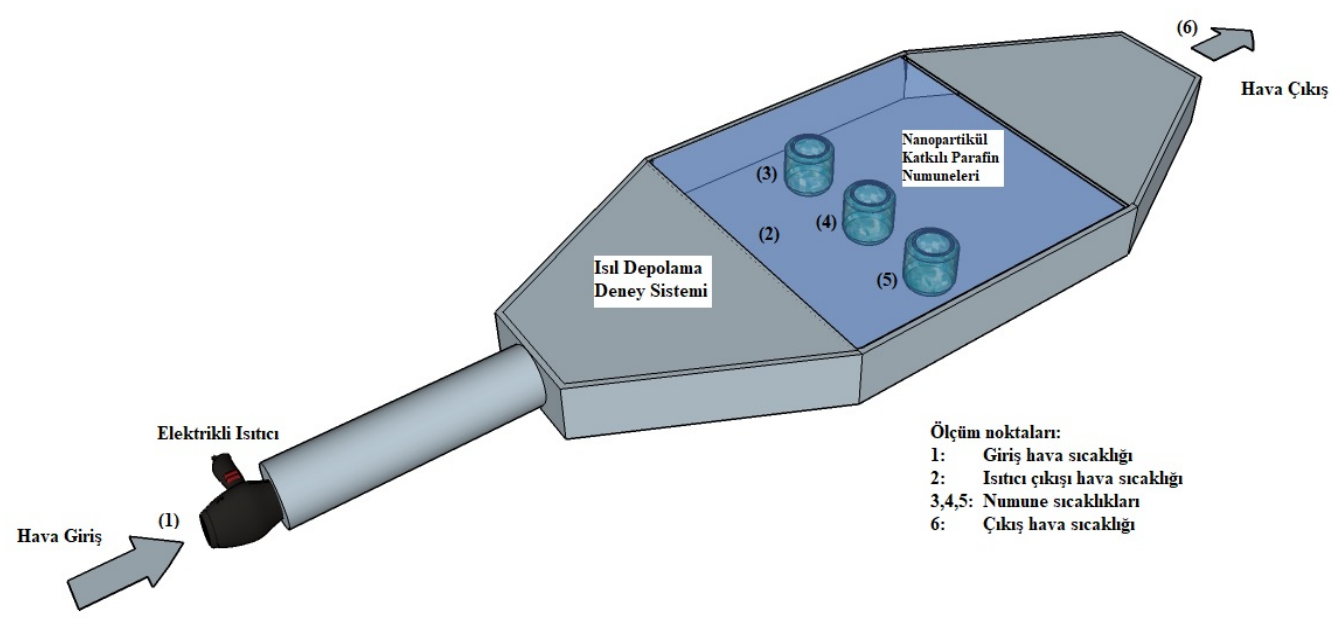

Şekil 3. Şarj ve deşarj döngülerinde kullanılan deney setinin şematik görünümü

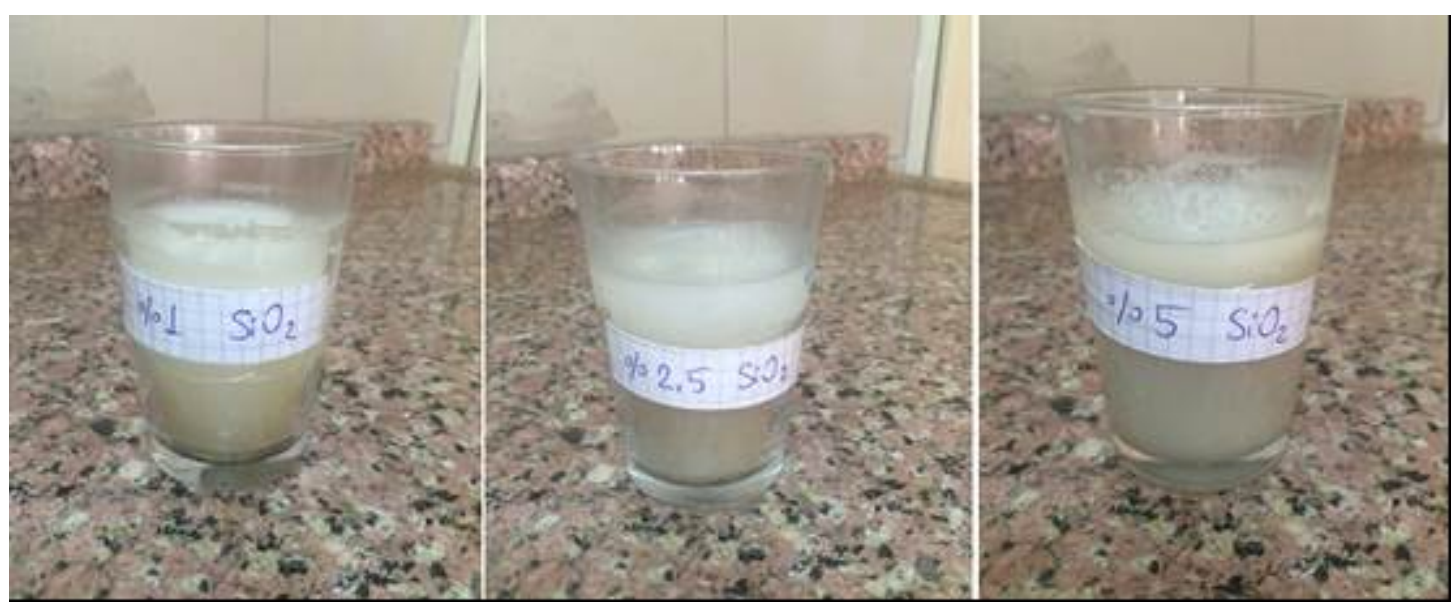

Şekil 4. $\mathrm{SiO}_{2}$ nanopartikül katkılı parafin

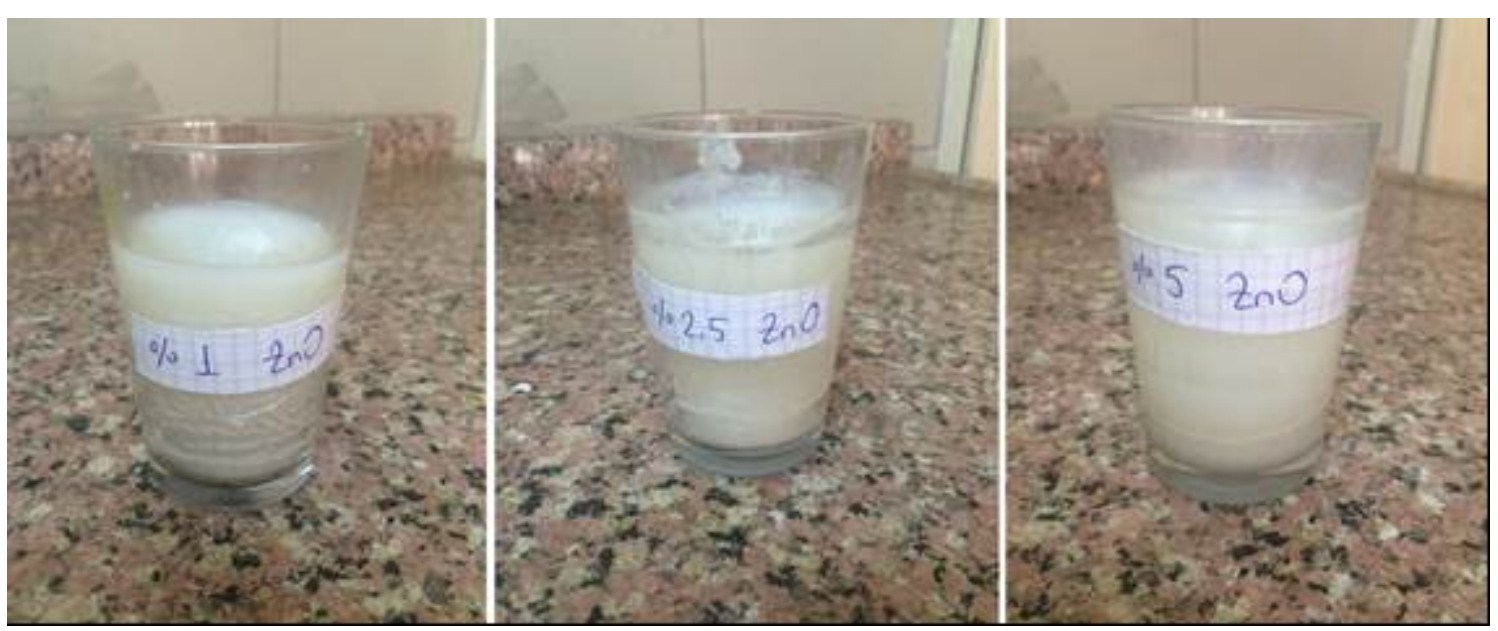

Şekil 5. ZnO nanopartikül katkılı parafin 


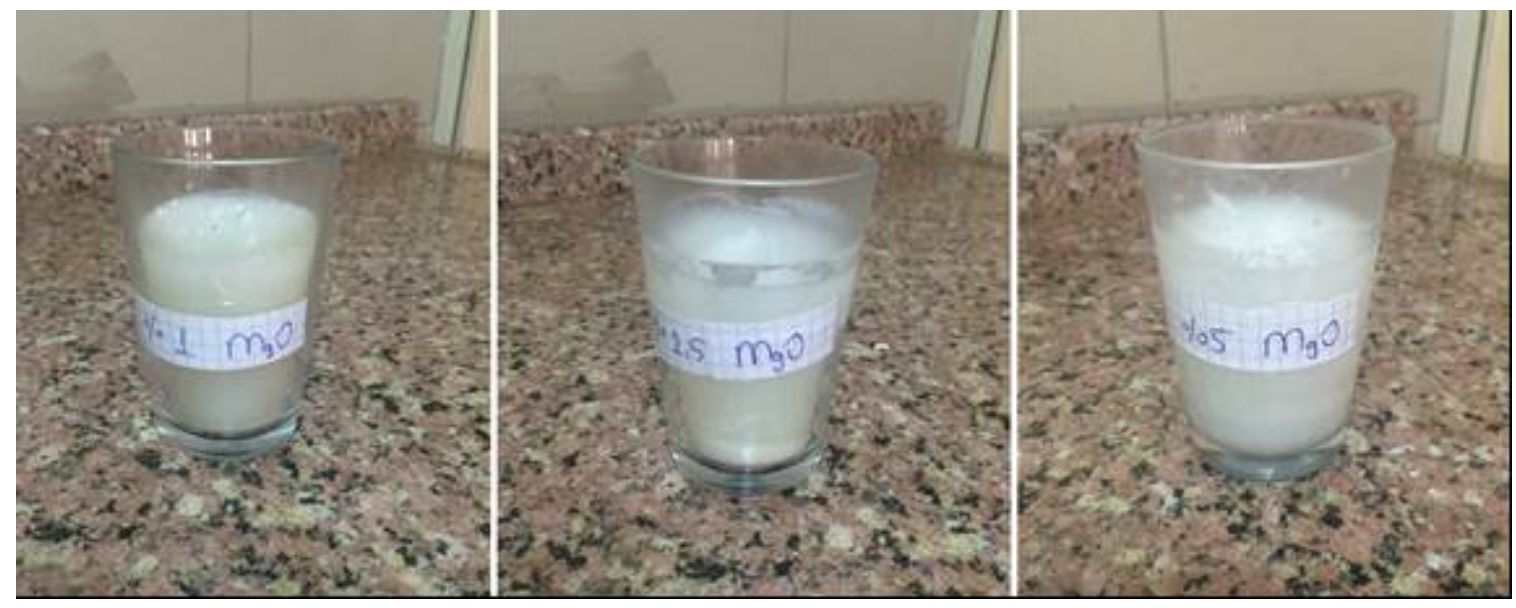

Şekil 6. MgO nanopartikül katkılı parafin

\section{BULGULAR VE TARTIŞMA (FINDINGS and DISCUSSION)}

Yapılan deneylerde öncelikle karıştırıcıdan alınan nanopartikül katkılı parafinler deney setine konularak donma işlemine tabi tutulmuş ve oda sıcaklığına getirilmiştir. Oda sıcaklığına getirilmiş olan ağırlıkça \%1, $\% 2.5$ ve $\% 5$ oranında $\mathrm{MgO}, \mathrm{SiO}_{2}$ ve $\mathrm{ZnO}$ nanopartiküllerini içeren parafinlerin şarj işlemleri Şekil 7, Şekil 8 ve Şekil 9'da sırasıyla gösterilmiştir. Şekil 7'den \%1 nano partikül katkısının parafinde önemli bir fark ortaya çıkarmadığı görülmüştür. $\mathrm{ZnO}$ ve $\mathrm{SiO}_{2}$ nano partikülün $\mathrm{MgO}$ nanopartikülüne göre erime sonrasında daha fazla sıcaklık artışına neden olduğu gözlemlenmiş̧tir. Nano ZnO katkılı parafin, 1540 saniyede 53.45 ${ }^{\circ} \mathrm{C}$ 'de erime başlamış ve erimeden sonra 2350 saniyeden $83.6{ }^{\circ} \mathrm{C}$ 'ye çıkmıştır. Nano $\mathrm{MgO}$ katkılı parafin ise 1540 saniyede $50.3{ }^{\circ} \mathrm{C}$ 'de erime başlamış ama sıcaklık artışı $\mathrm{SiO}_{2}$ ve $\mathrm{ZnO}$ katkılı parafine yetişememiştir. Şekil 8'den \%2.5 nanopartikül katkısının parafinin erime noktasını aşağıya çektiği ve $\mathrm{SiO}_{2}$ nanopartikül katkılı parafinin erimede daha yüksek sıcaklıklara çıkarken erimeden sonra diğer nanopartiküllere göre daha düşük sıcaklıklarda kaldığı gözlemlenmiştir. $\mathrm{ZnO}$ nanopartikülünün erime ile birlikte diğerlerinden ayrıştığı görülmüştür. Şekil 9'dan \%5 nanopartikül katk1lı parafinin şarj işleminde $\mathrm{MgO}$ ve $\mathrm{ZnO}$ nanopartiküllerin aynı etkiyi yaptığı, erimede $\mathrm{SiO}_{2}$ nanopartikülden daha düşük sıcaklığa fakat erimeden sonra daha yüksek sıcakılıklara çıktıkları görülmüştür. $\mathrm{SiO}_{2}$ nanopartikül katkılı parafinin erimede diğer nanopartikül katkılılara göre daha yüksek sıcaklıklara çıkarken erimeden sonra daha düşük sıcaklıklarda kaldığı tespit edilmiştir. ZnO nanopartikül katkılı parafinin erime ile birlikte diğerlerinden ayrıştığı görülmüştür.

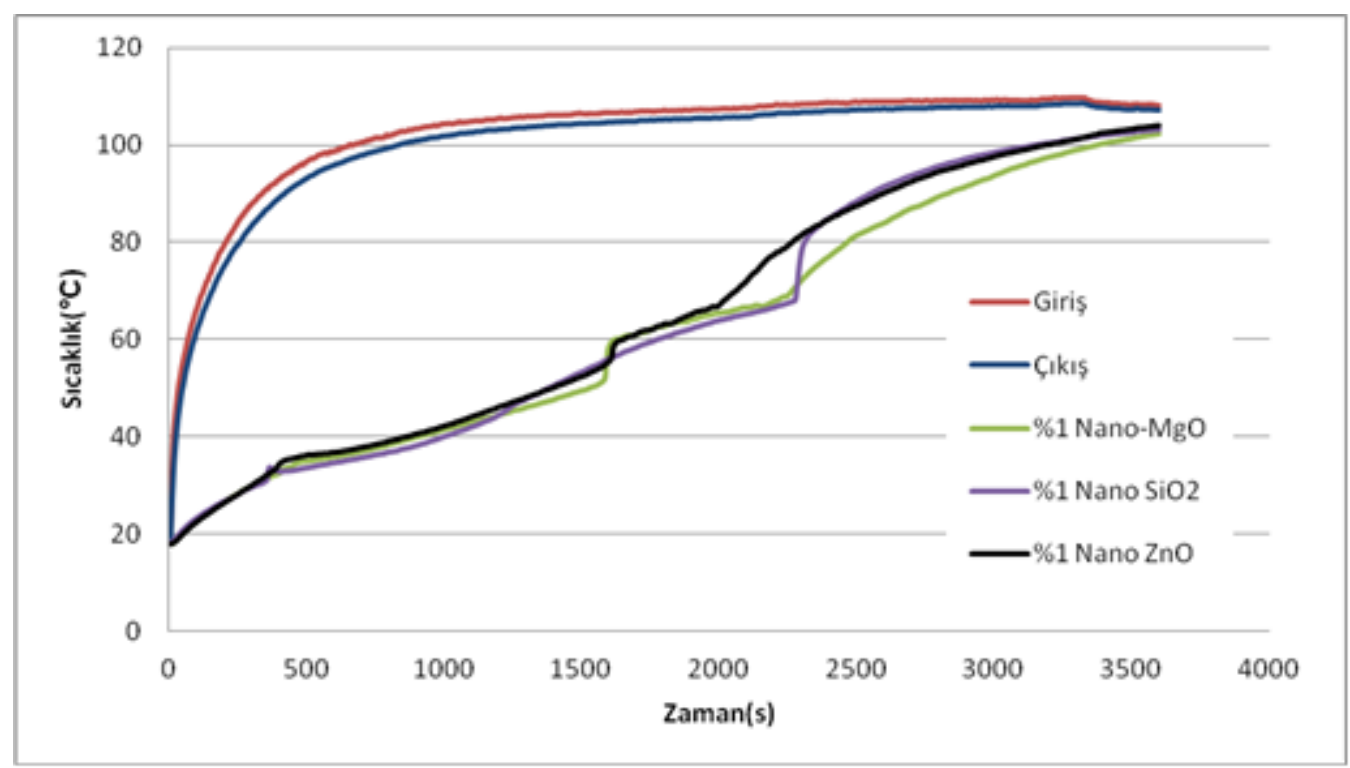


Şekil 7.\%1 nano $\mathrm{ZnO}, \mathrm{MgO}$ ve $\mathrm{SiO}_{2}$ katkılı parafinlerin şarj işlemi

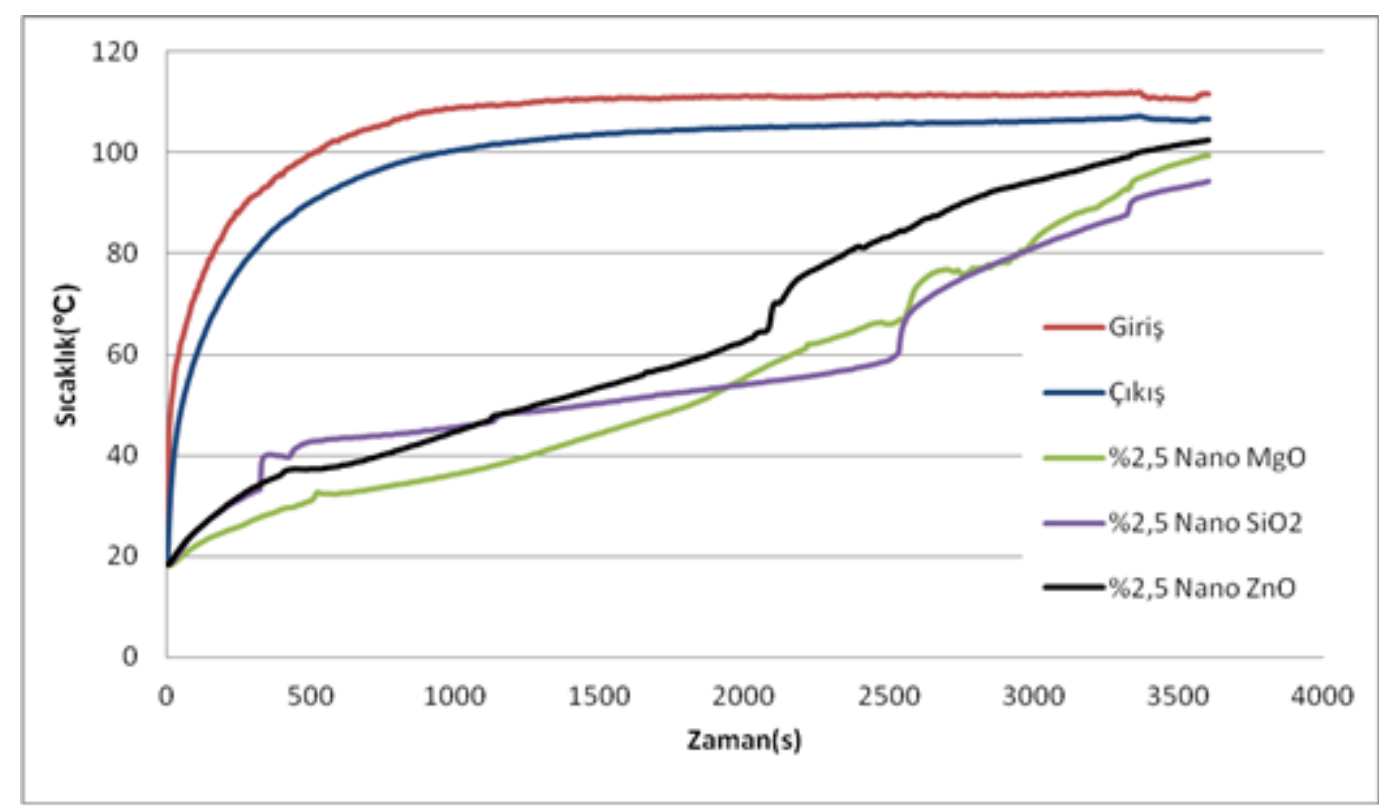

Şekil 8. \%2.5 nano $\mathrm{ZnO}, \mathrm{MgO}$ ve $\mathrm{SiO}_{2}$ katkılı parafinlerin şarj işlemi

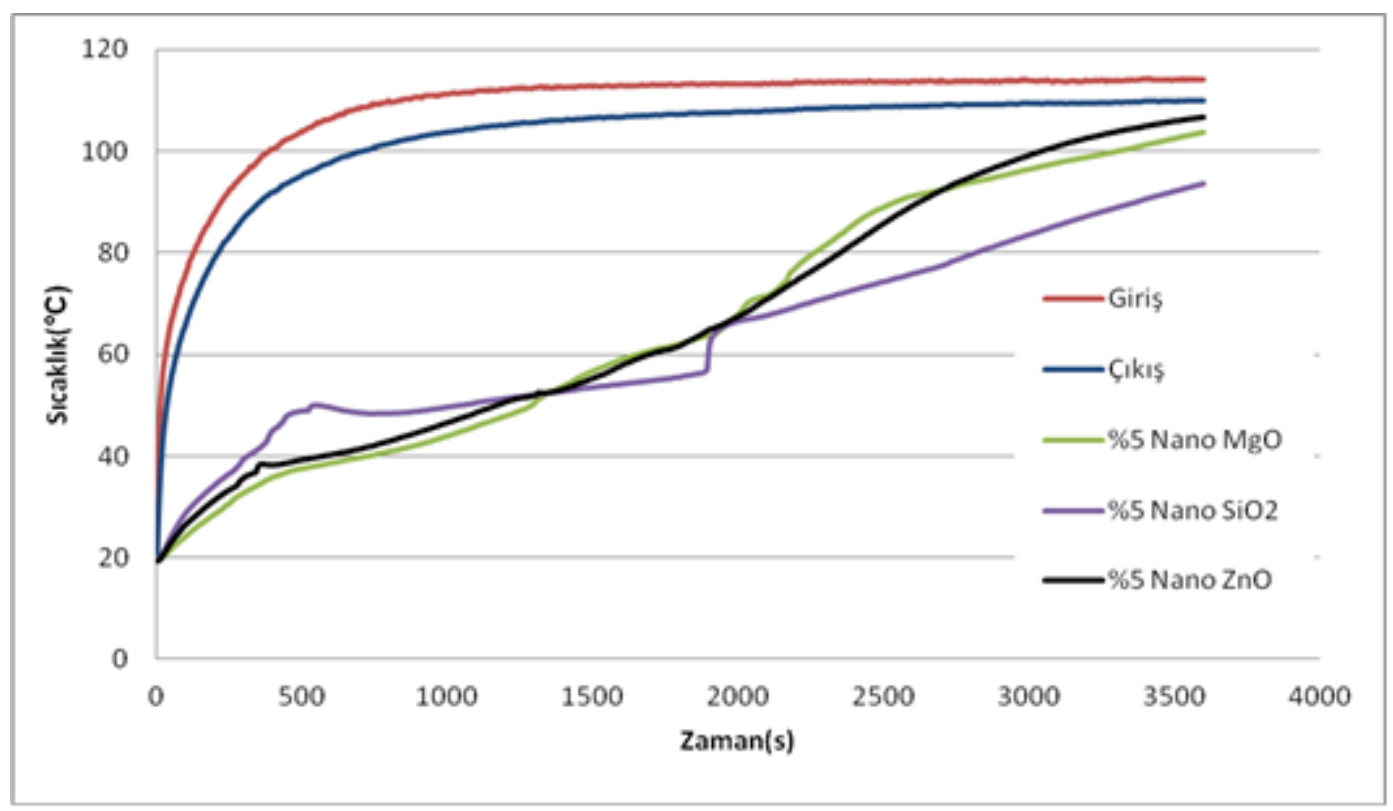

Şekil 9. \%5 nano $\mathrm{ZnO}, \mathrm{MgO}$ ve $\mathrm{SiO}_{2}$ katkılı parafinlerin şarj işlemi

Şekil 10, Şekil 11 ve Şekil 12'de ise ağırlıkça \%1, \%2.5 ve \%5 oranında $\mathrm{MgO}, \mathrm{SiO}_{2}$ ve $\mathrm{ZnO}$ nanopartikülleri içeren parafinlerin deşarj işlemleri gösterilmiştir. Şekil 10'dan \%1 nanopartkül katkısının parafinin deşarj işleminde önemli bir etkisi olmadığ görülmüştür. Şekil 11'den $\mathrm{SiO}_{2}$ katkılı parafinin daha önce donduğu ve donmadan sonra $\mathrm{SiO}_{2}$ nanopartkül katkılı parafinde sıcaklığın daha fazla düştüğü belirlenmiştir. 
Grafikler incelendiğinde $\mathrm{ZnO}$ ilaveli parafinin her üç oranda da diğer iki numuneden daha önce donmaya başladığı görülmektedir. $\mathrm{MgO}$ katkılı parafinlerin ise sıcaklıklarındaki düşme hızının diğer iki numuneye göre daha fazla olduğu fakat $\mathrm{ZnO}$ katkılı parafine göre daha geç donmaya başladığ 1 görülmektedir. $\mathrm{SiO}_{2}$ katkılı numunelerin ise şarj durumunda daha geç erimeye başladığı gibi deşarj durumunda da daha geç donmaya başladığı görülmektedir. Ayrıca nanopartikül ilavesinin artışına bağlı olarak her üç numunede de donma süresinin biraz daha kısaldığı gözlemlenmiştir.

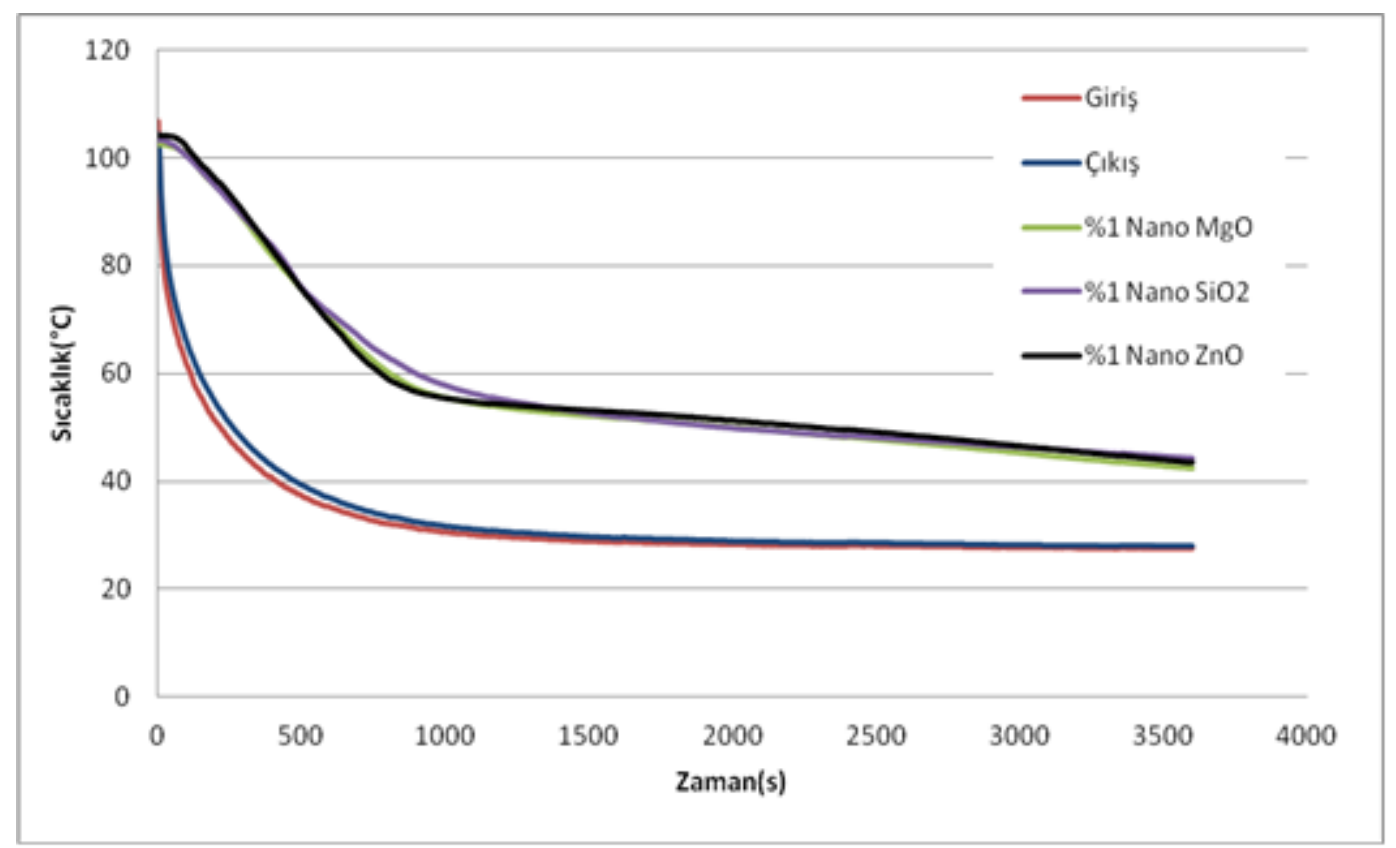

Şekil 10. \%1 nano $\mathrm{ZnO}, \mathrm{MgO}$ ve $\mathrm{SiO}_{2}$ katkılı parafinin deşarj işlemi

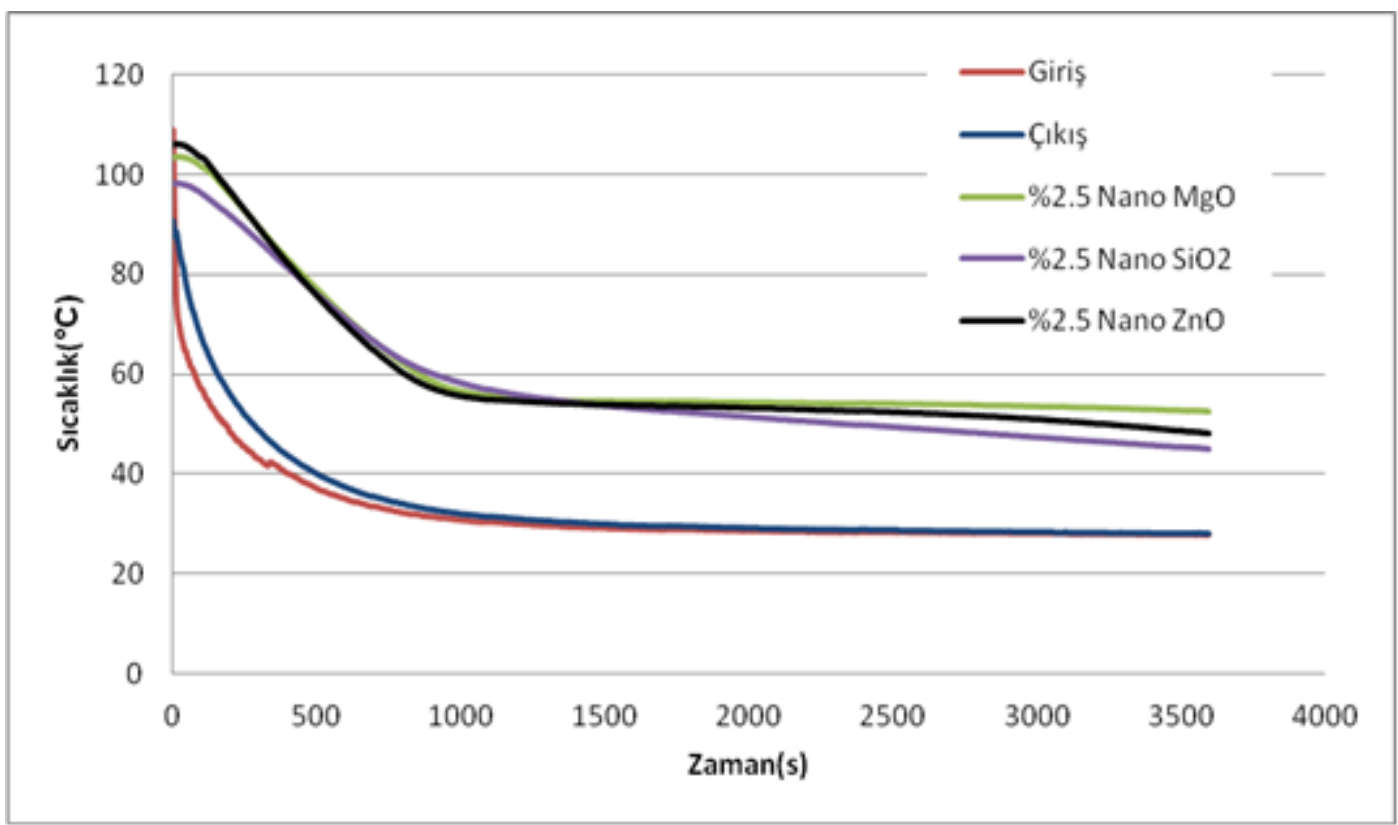

Şekil 11. \%2.5 nano $\mathrm{ZnO}, \mathrm{MgO}$ ve $\mathrm{SiO}_{2}$ katkılı parafinin deşarj işlemi 


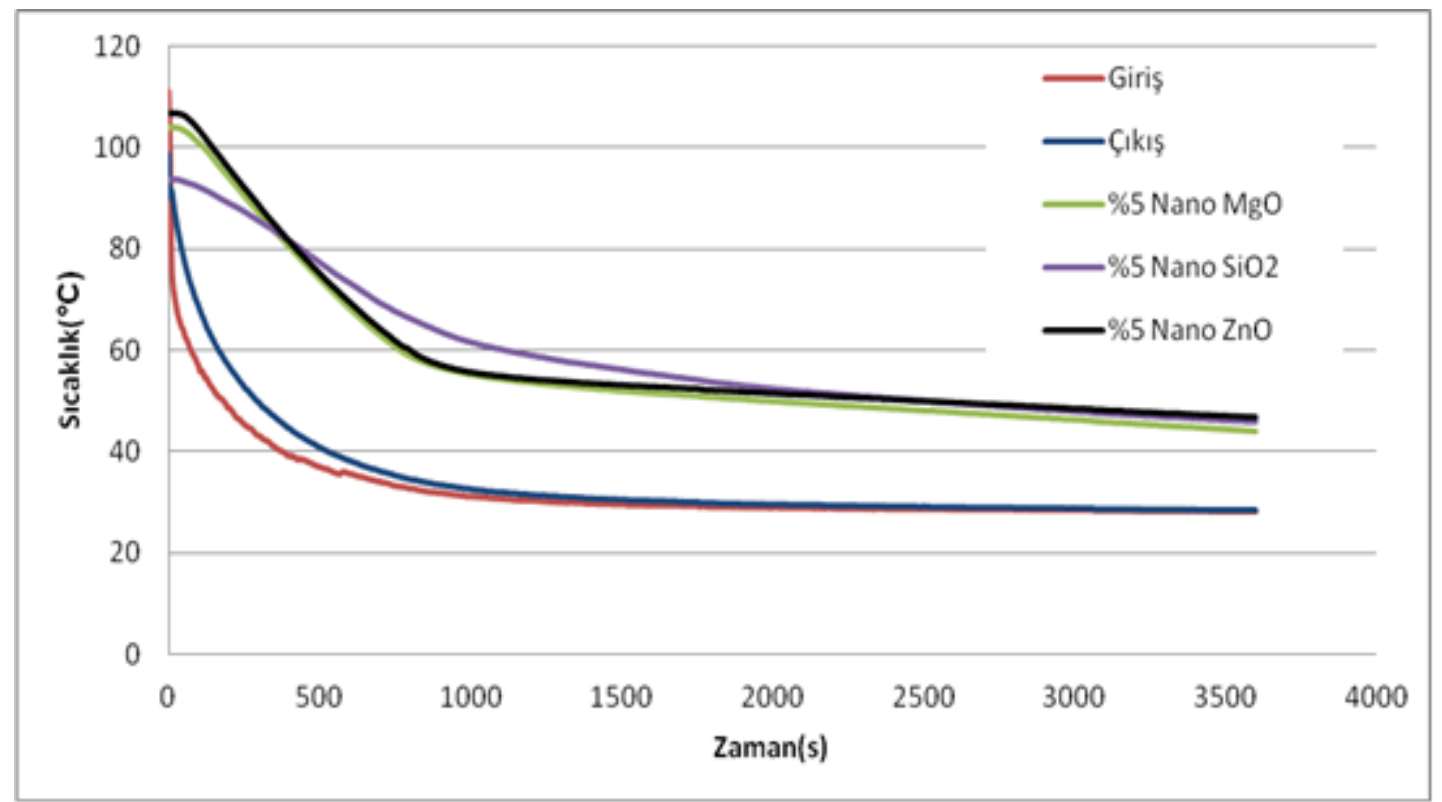

Şekil 12. \%5 nano $\mathrm{ZnO}, \mathrm{MgO}$ ve $\mathrm{SiO}_{2}$ katkllı parafinin deşarj işlemi

\section{SONUÇ}

Gizli 1sıyı depolayabilen maddeler olan FDM'lerden parafinin 1sıyı depolama sürecindeki en temel sorunu düşük $1 s ı$ iletkenliğe sahip olmasıdır. FDM'lere nanopartiküllerin eklenmesi son yıllarda geliştirilip üzerine yoğun araştırmaların yapıldığ kütle oranlarında kullanılmasının parafinin ısıl iletkenliğine ve dolayısıyla da erime/donma sürelerine olan etkisi deneysel olarak incelenmiştir. \%1, \%2.5 ve \%5 kütle oranlarında $\mathrm{MgO}, \mathrm{SiO}_{2}$ ve $\mathrm{ZnO}$ nanopartikülleri parafine ilave edilip şarj/deşarj işlemleri incelenmiştir. \%1 nanopartikül katkısının parafinin sarj ve deşarjında önemli etki yapmadığı tespit edilmiştir. \%2.5 nanopartikül katkılı şarj işleminde; ZnO katkılı parafinde sıcaklık artışının genel olarak daha iyi olduğu belirlenmiştir. Ancak \%2.5 nanopartikül katkılı parafinin deşarj işleminde donma ve donma sonrası için $\mathrm{SiO}_{2}$ nanopartikül katkılı parafinin ayrıştığ 1 görülmüştür. \%5 katkı1ı şarj işleminde ise erimede $\mathrm{SiO}_{2}$ nanopartikülünün, erime ve erime sonrasında ise $\mathrm{MgO}$ ve $\mathrm{ZnO}$ nanopartiküllerinin benzer davranış göstererek $\mathrm{SiO}_{2}$ nanopartikülünden daha iyi performans gösterdikleri tespit edilmiştir. \%5 katkılı deşarj işleminde ise donma öncesi $\mathrm{MgO}$ ve $\mathrm{ZnO}$ nanopartikülünün benzer davranış gösterdikleri ve $\mathrm{SiO}_{2}$ göre daha iyi performans gösterdikleri gözlemlenmiştir. Sonuç olarak ise $\mathrm{ZnO}$ nanopartikülün parafinde şarj/deşarj işlemlerinde daha iyi performans gösterdiği ve \%2.5 kütle oranın daha iyi olduğu tespit edilmiştir. Nanopartikül katkısı etkisinin tam olarak belirlenmesi için şarj ve deşarj işlemlerinin bir döngü ile daha fazla yapılması ve belirli döngü sayısı sonrası nanopartikülün çökme, topaklaşma ve homojen dağılışı da incelenmesi gerekmektedir.

\section{KAYNAKLAR (REFERENCES)}

[1] Alva, G., Lin, Y. \& Fang, G. “An Overview of Thermal Energy Storage Systems”. Energy, 144:341$378,2018$.

[2] Chen, M., He, Y., Ye, Q., Zhang, Z. \& Hu, Y. "Solar Thermal Conversion and Thermal Energy Storage of $\mathrm{CuO} /$ Paraffin Phase Change Composites". International Journal of Heat and Mass Transfer, 130:1133-1140, 2019. 
[3] Saydam, V. "Thermal Energy Storage Using Paraffin Wax and Stability Study of The Phase Change Material Containing Nanoparticles". Memorial University of Newfoundland, Faculty of Engineering \& Applied Science, Master of Engineering, St. Johns's Newfoundland and Labrador, 2018.

[4] Beyhan, B., Cellat, C., Karahan, O., Konuklu, Y., Dündar, C., Güngör, C. \& Paksoy, H. "Bina Yap1 Malzemeleri İçin Mikrokapsüllenmiş Faz Değiştiren Madde Geliştirilmesi'. Teskon 2015 Bildiriler Kitab1, 1469-1480, 2015.

[5] Şahan, N. "Faz Değiştiren Maddelerin Nano Malzemelerle Kullanımının Araştırılması'. Çukurova Üniversitesi, Fen Bilimleri Enstitüsü, Adana. Yüksek Lisans Tezi, 2011.

[6] Ceylan, İ., Zuhur, S. \& Gürel, A. “Isı Depolama Yöntemleri ve Uygulamaları'. Kasım-Aralık TTMD Dergisi, 2017.

[7] Fan, L. \& Khodadadi, J.M. "Thermal Conductivity Enhancement of Ohase Change Materials for Thermal Energy Storage:A Review”. Renewable and sustainable Energy Reviews, 15:24-46, 2011.

[8] Kuru, A. \& Aksoy, S. "Faz Değiştiren Maddeler ve Tekstil Uygulamaları'. Tekstil ve Mühendis Dergisi, 19:86, 41-48, 2012.

[9] Konuklu, Y. "Mikrokapsüllenmiş Faz Değiştiren Maddelerde Termal Enerji Depolama İle Binalarda Enerji Tasarrufu”. Çukurova Üniversitesi, Fen Bilimleri Enstitüsü, Adana, Doktora Tezi, 2009.

[10] Taşkıran, A. "Nanoboyutlu Parçacık Katkılı Yeni Nesil Faz Değiştiren Maddelerin Deneysel Olarak İncelenmesi”. Fırat Üniversitesi, Fen Bilimleri Enstitüsü,Elazığ. Yüksek Lisans Tezi, 2013.

[11] Koşan, M. \& Aktaş, M. "Faz Değiştiren Malzemelerle Termal Enerji Depolayan Bir Isı Değiştiricisinin Sayısal Analizi’’. Politeknik Dergisi, 21(2): 403-409, 2018.

[12] Yılmaz, S. "Soğutma Uygulamaları İçin Faz Değiştiren Maddelerde Termal Enerji Depolama". Çukurova Üniversitesi, Fen Bilimleri Enstitüsü, Adana. Yüksek Lisans Tezi, 2008.

[13] Fan, L., Khodadadi, J.M. \& Babaei, H. "Thermal conductivity enhancement of nanostructure-based colloidal suspensions utilized as phase change materials for thermal energy storage: A review". Renewable and Sustainable Energy Reviews, 24:418-444, 2013

[14] Dhaidan, N.S. "Nanostructures assisted melting of phase change material in various cavities". Applied Thermal Engineering 111:193-212, 2017.

[15] Sebtı, S.S., Mastıan1, M., Mirzae1, M., Dadvand, A., Kashan1,S. \& Hosseın1, S.A. "Numerıcal study of the melting of nano-enhanced phase change material in a square cavity". Journal of Zhejiang University - Science A: Applied Physics \& Engineering, 14(5):307-316, 2013.

[16] Elbahjoui, R. \& Quarnia, H., "Performance Evaluation of a Solar Thermal Energy Storage System Using Nanoparticle-Enhanced Phase Change Material". International Journal of Hydrogen Energy, 44:2013-2028, 2018.

[17] Wu, S., Zhu, D. \& Huang, J. "Preparation and melting/freezing characteristics of Cu/Paraffin nanofluid as phase change material (PCM)”. Energy Fuels, 24, 1894-98, 2010.

[18] Ho, C.J. \& Gao, J.Y. "Preparation and thermophysical properties of nanoparticle-in-paraffin emulsion as phase change material". International Communications in Heat and Mass Transfer, 36, 467-70, 2009.

[19] Jesumathy, S., Udayakumar, M. \& Suresh, S. "Experimental Study of Enhanced Heat Transfer By Addition of CuO Nanoparticles". Heat Mass Transfer, 48:965-978, 2012. 
[20] Fan, L.W., Fang, X., Wang, X., Zeng, Y., Xiao, Y.Q., Yu, Z.T., Xu, X., Hu, Y.C.\& Cen, K.F. “Effects of Various Carbon Nanofillers on The Thermal Conductivity and Energy Storage Properties of ParaffinBased on Nanocomposite Phase Change Materials”. Applied Energy, 110:163-172, 2013.

[21] Wang, J., Xie, H., Li, Y. \& Xin, Z. "PW based phase change nanocomposites containing $\gamma$-Al2O3”. J Therm Anal Calorim, 102:709-713, 2010.

[22] Parlak, M., Temel, Ü.N., Sömek, K. \& Yapıcı, K. "Experimental Investigatıon of Transient Thermal Response of Phase Change Material Embedded by Graphene Nanoparticles in Energy Storage Module". 15th IEEE ITHERM Conference, 978-1-4673-8121-5, 2016.

[23] Amin, M., Afriyanti, F. \& Putra, N. "Thermal Properties of Paraffin Based Nano-Phase Change Material as Thermal Energy Storage'. 2nd International Tropical Renewable Energy Conference, 2018.

[24] Tan, F.L., Rabienataj Darzi, A.A. \& Hosseinizadeh, S.F. "Numerical Investigations of Unconstrained Melting of Nano-Enhanced Phase Change Material (NEPCM) Inside a Spherical Container". International Journal of thermal Sciences, 51:77-83, 2012.

[25] Nourani, M., Hamdami, N., Keramat, J., Moheb, A. \& Shahedi, M. "Thermal Behavior of ParaffinNano-A12O3 Stabilized by Sodium Stearoyl Lactylate As a Stable Phase Change Material With High Thermal Conductivity". Renewable Energy 88: 474-482, 2016.

[26] Mandal, K.S., Kumar, S., Singh, P.K., Mishra, K.S., Bishwakarma, H., Choudhry, N.P., Nayak, R.K. \& Das, A.K. "Performance Investigation of CuO-Paraffin Wax Nanocomposite in Solar Water Heater During Night". Thermochimica Acta 671: 36-42, 2019.

[27] Kim, S. \& Drzal, L.T. "High latent heat storage and high thermal conductive phase change materials using exfoliated graphite nanoplatelets". Solar Energy Materials \& Solar Cells 93: 136-142, 2009.

[28] Ebrahimi, A. \& Dadvand, A. "Simulation of Melting of A Nano-Enhanced Phase Change Material (NePCM) in A Square Csvity With Two Heat Source-Sink Pairs". Alexandria Engineering Journal, 54:1003-1017, 2015.

[29] Li, M. "A Nano-Graphite/Paraffin Phase Change Material With High Thermal Conductivity". Applied Energy 106:25-30, 2013. 